\title{
DATA REPOS
}

ITORY ITEM

\section{General Sampling Methodology}

M.C. Harvey collected samples from New Zealand and Italy. C.M Belcher collected samples from all North American locations except Teapot Dome (Wyoming). Sources of other samples are detailed below.

\section{New Zealand (Woodside Creek) and Italian (Umbria/Marche) Sections}

The K/P boundary clay layer was not wide enough ( $\sim 10 \mathrm{~mm}$ width $)$ to make on-site division and sub-sampling of the boundary layer practical, so the clay was removed as bulk, undifferentiated sample. No horizontal sampling was undertaken.

i) Small pieces of K/P boundary clay were extracted from the clay layer using a metal alloy peg ( $20 \mathrm{~cm}$ length) that was first cleaned with water and cotton cloth. The extracted clay pieces were transferred onto aluminum foil by gloved (latex) hand. The peg was able to extract clay to a maximum depth of approximately $5 \mathrm{~cm}$ from the exposed surface material.

ii) The extracted K/P boundary clay $(\sim 100 \mathrm{~g})$ was then wrapped in two layers of aluminum foil and the foil parcel labeled and placed in plastic zip-lock bags.

Additional control samples were collected from adjacent top-soils. Samples were collected from sediments spanning the $\mathrm{K} / \mathrm{P}$ boundary from Late Cretaceous $(0.5 \mathrm{~m}$ below boundary), through Early Paleocene ( $0.5 \mathrm{~m}$ above the boundary), at regular intervals ( 0.1 $\mathrm{m})$.

For the New Zealand boundary sediments only, prior to chemical pre-treatment, the boundary clay was subdivided into three sub-samples: (a) darker crusty basal layer, (b) middle red layer, and (c) hard, darker upper layer. 


\section{Denmark (Stevns Klint)}

Samples of the K/P boundary fish clay, layers 3 and 4+ were provided by Crawford Elliot of Georgia State University, USA. K/P boundary sediment was extracted from the outcrop using a hammer and chisel. The K/P boundary clay was located beneath an under-hang of $\sim 0.5 \mathrm{~m}$. Fresh block sample was obtained from a depth of $>5 \mathrm{~cm}$. Samples were transferred by hand into plastic bags. All sample material was collected from the same outcrop accessible from car park path south of Hojerup Church. There were no horizontal distances between samples (Elliot, pers. comms.).

\section{Spain - Caravaca}

Samples of the K/P boundary at Barranco del Gredero were provided by Cristiano Lana, Department of Earth Science and Engineering, Imperial College, London. Fresh sample was obtained using a pocketknife with an aluminum handle. Samples were transferred by hand into plastic bags. All sample material was collected from the same outcrop, located 500 meters from a gravel road and approximately $5 \mathrm{~km}$ from the nearby town of Alicant. There were no horizontal distances between samples.

Prior to chemical pre-treatment, the boundary clay was subdivided into two sub-samples:

(i) darker crumbly material, and (ii) lighter material with more homogenous texture.

\section{North America}

Four K/P sections were excavated and encased in plaster (Ricks Place [Montana], Mud Buttes [North Dakota], Rock Creek East [Saskatchewan], Wood Mountain Creek [Saskatchewan]). Teapot Dome (Wyoming) was provided by Margaret Collinson, Department of Geology, Royal Holloway University of London, Egham, Surrey, UK. 


\begin{tabular}{|c|c|c|c|c|c|c|c|c|c|c|c|}
\hline & ireba & all La & yer Sa & & & & & & & Contr & \\
\hline & (i) & & (ii) & (iii) & (iv) & (v) & (vi) & (vii) & (viii) & (ii) & (iii) \\
\hline & 5 & 4 & 10 & 3 & 5 & 16 & 3 & 21 & 5 & 70 & 35 \\
\hline & 2 & 2 & 25 & 20 & 5 & 8 & 9 & 5 & & 68 & \\
\hline & 4 & 2 & 14 & 20 & 5 & & 7 & 5 & & 55 & \\
\hline & 2 & 4 & & & 7 & & 6 & 6 & & 30 & \\
\hline & 32 & 2 & & & 10 & & & 2 & & 23 & \\
\hline & 3 & 5 & & & 15 & & & 20 & & & \\
\hline & 22 & 2 & & & 8.5 & & & & & & \\
\hline & 23 & 3 & & & 6 & & & & & & \\
\hline & 2 & 3 & & & 12 & & & & & & \\
\hline & 22 & 2 & & & 10 & & & & & & \\
\hline & 22 & 2 & & & 8 & & & & & & \\
\hline & 4 & 2 & & & 16 & & & & & & \\
\hline & 42 & 2 & & & 10 & & & & & & \\
\hline & 22 & 2 & & & 9 & & & & & & \\
\hline & 32 & 2 & & & & & & & & & \\
\hline & 42 & 2 & & & & & & & & & \\
\hline & 33 & 3 & & & & & & & & & \\
\hline & 5 & & & & & & & & & & \\
\hline & 1 & & & & & & & & & & \\
\hline & 2 & & & & & & & & & & \\
\hline & 4 & & & & & & & & & & \\
\hline & 5 & & & & & & & & & & \\
\hline Mean $(\mu \mathrm{m})$ & 2 & .8 & 16.3 & 14.3 & 9.0 & 12.0 & 6.3 & 9.8 & 5.0 & 49.2 & 35 \\
\hline$\underline{\text { Std Dev }}$ & 1 & .2 & 7.8 & 9.8 & 3.5 & 5.7 & 2.5 & 8.4 & & 21.6 & \\
\hline & & & ounda & & Control & & & & & & \\
\hline Overall Mea & $\operatorname{an}(\mu \mathrm{r}$ & & 6.1 & & 46.8 & & & & & & \\
\hline Std Dev & & & 5.5 & & 20.2 & & & & & & \\
\hline
\end{tabular}

Table DR1: WOODSIDE CREEK CARBON CENOSPHERE DIAMETERS 


\begin{tabular}{|c|c|c|}
\hline & $\begin{array}{r}\text { Layers } 3 \& 4 \\
\text { sample (iii) }\end{array}$ & \begin{tabular}{|c} 
Layers 4+ \\
sample (v)
\end{tabular} \\
\hline \multicolumn{3}{|r|}{12} \\
\hline & 4 & 9 \\
\hline & 6 & 7 \\
\hline & 7 & 6 \\
\hline \multicolumn{3}{|c|}{6} \\
\hline \multicolumn{3}{|c|}{4} \\
\hline \multicolumn{3}{|c|}{4} \\
\hline \multicolumn{3}{|c|}{3} \\
\hline \multicolumn{3}{|c|}{4} \\
\hline \multicolumn{3}{|c|}{8} \\
\hline \multicolumn{3}{|c|}{6} \\
\hline \multicolumn{3}{|c|}{4} \\
\hline Mean $(\mu \mathrm{m})$ & 5.1 & 8.5 \\
\hline$\underline{\text { Std Dev }}$ & 1.5 & 2.6 \\
\hline Overall Me & im) & 5.9 \\
\hline Std Dev & & 2.3 \\
\hline
\end{tabular}

Table DR2: STEVNS KLINT CARBON CENOSPHERE DIAMETERS

\begin{tabular}{|c|c|c|c|c|c|c|c|}
\hline & \multicolumn{3}{|c|}{ Ejecta Layer Samples } & \multicolumn{4}{|c|}{ Lower Satiny Layer Samples } \\
\hline & (i) & (iii) & (iv) & (i) & (ii) & (iii) & (iv) \\
\hline & 18 & 30 & \multirow[t]{7}{*}{40} & 25 & 60 & \multirow[t]{7}{*}{5} & 18 \\
\hline & 30 & 23 & & 15 & 25 & & 9 \\
\hline & 40 & 22 & & 35 & 50 & & 15 \\
\hline & 30 & 10 & & 12 & 45 & & 20 \\
\hline & 30 & 17 & & 25 & & & 45 \\
\hline & \multirow[t]{2}{*}{25} & \multirow[t]{2}{*}{12} & & & & & 18 \\
\hline & & & & & & & 30 \\
\hline Mean $(\mu \mathrm{m})$ & 28.8 & 19.0 & \multirow[t]{2}{*}{40.0} & 22.4 & 45.0 & \multirow[t]{2}{*}{5.0} & 22.1 \\
\hline \multirow[t]{2}{*}{ Std Dev } & 7.2 & 7.5 & & 9.2 & 14.7 & & 11.9 \\
\hline & & & \multicolumn{2}{|l|}{ Ejecta } & \multicolumn{2}{|c|}{ Lower Satiny } & Combined \\
\hline \multicolumn{3}{|c|}{ Overall Mean $(\mu \mathrm{m})$} & \multicolumn{2}{|l|}{25.2} & \multicolumn{2}{|c|}{26.6} & 26.0 \\
\hline \multicolumn{3}{|l|}{ Std Dev } & 9.4 & & \multicolumn{2}{|c|}{15.6} & 13.1 \\
\hline
\end{tabular}

Table DR3: ROCK CREEK EAST CARBON CENOSPHERE DIAMETERS 
吾

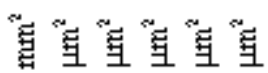
号员号员 回守家 实

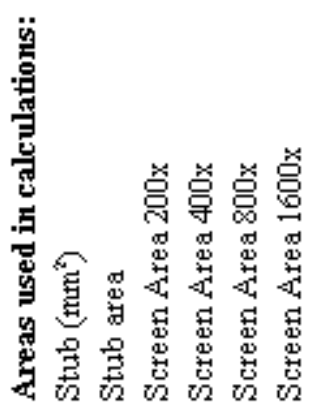

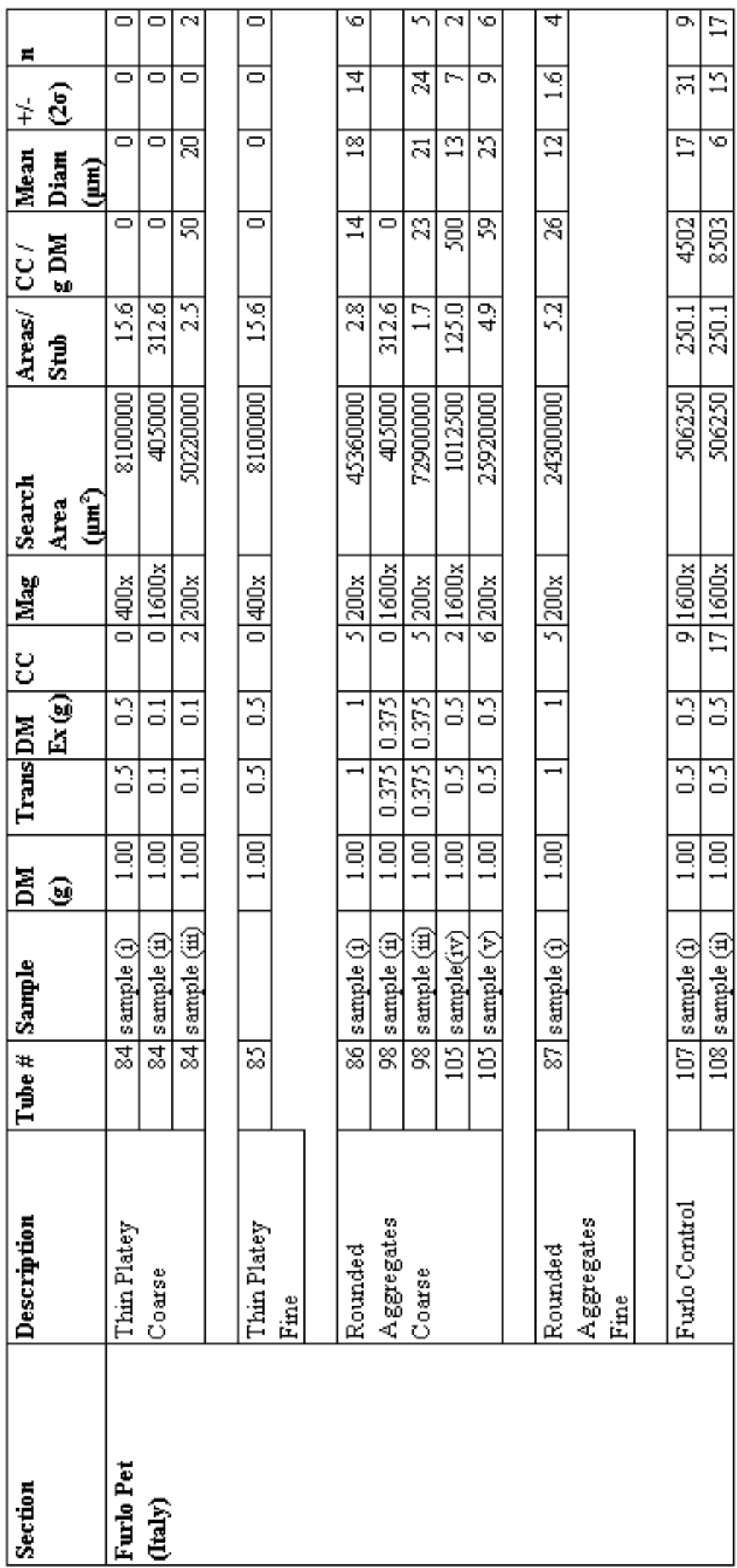

Table DR4: RAW DATA 


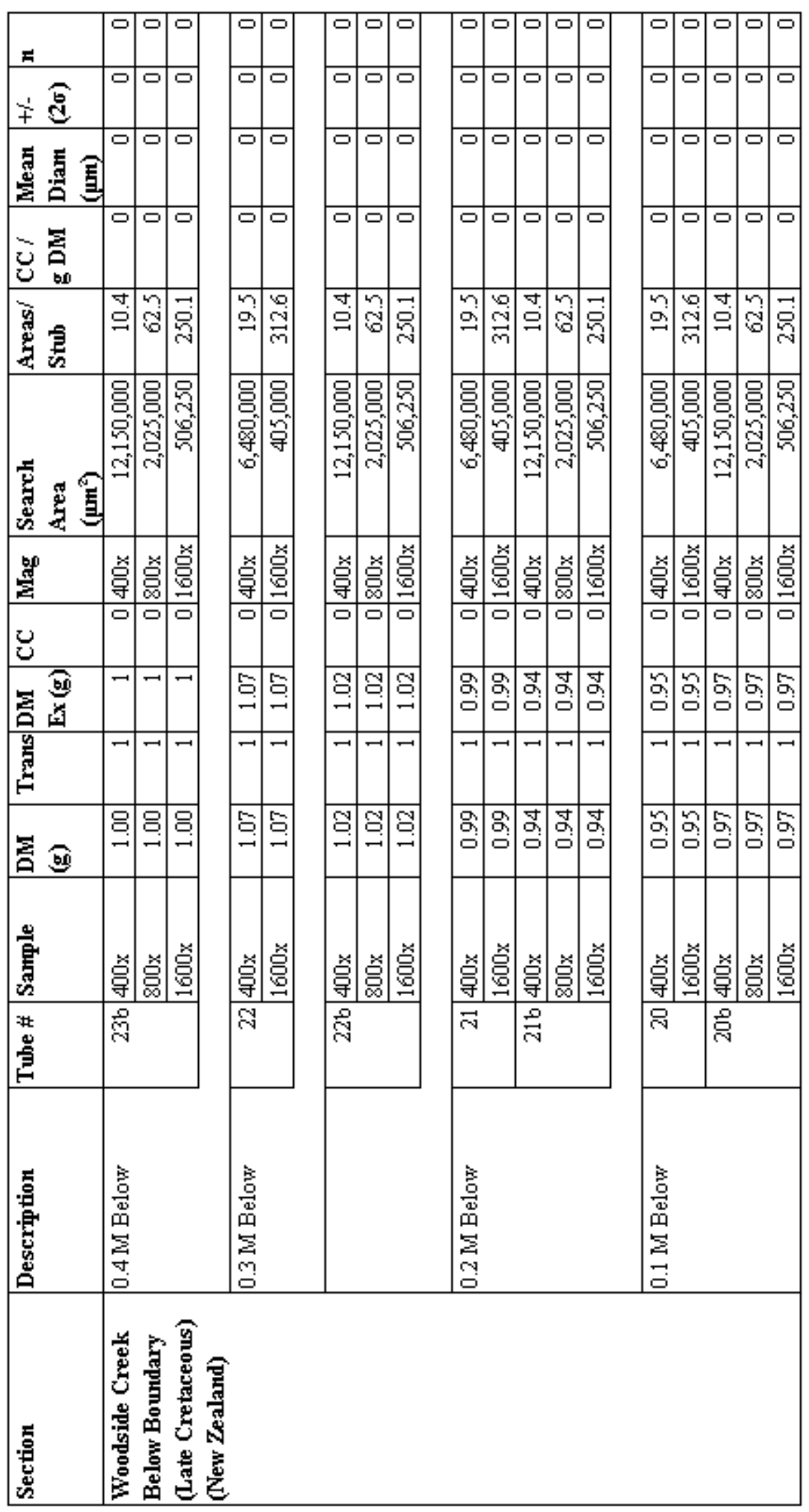

Table DR4: continued 


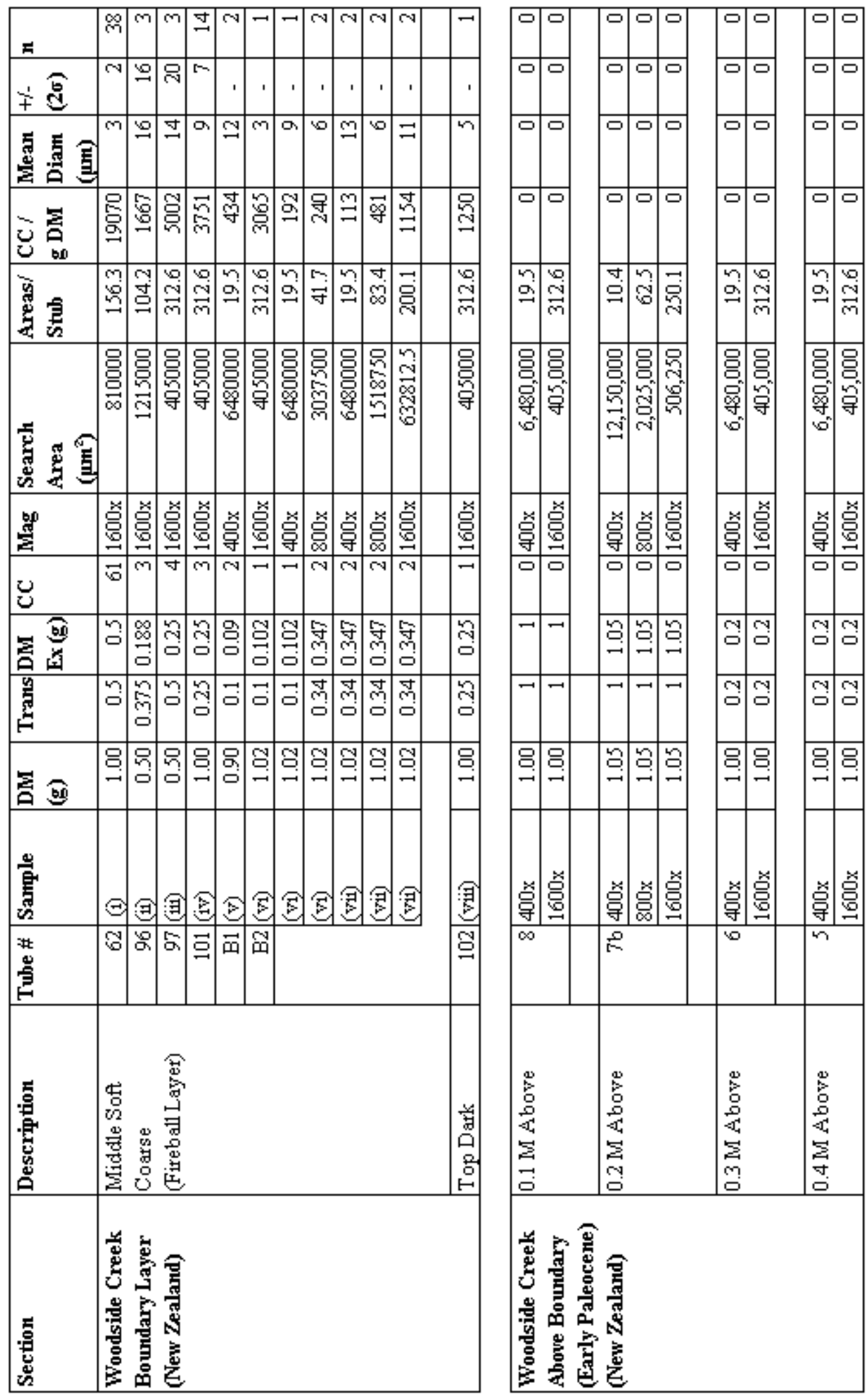


Harvey et al., page 8

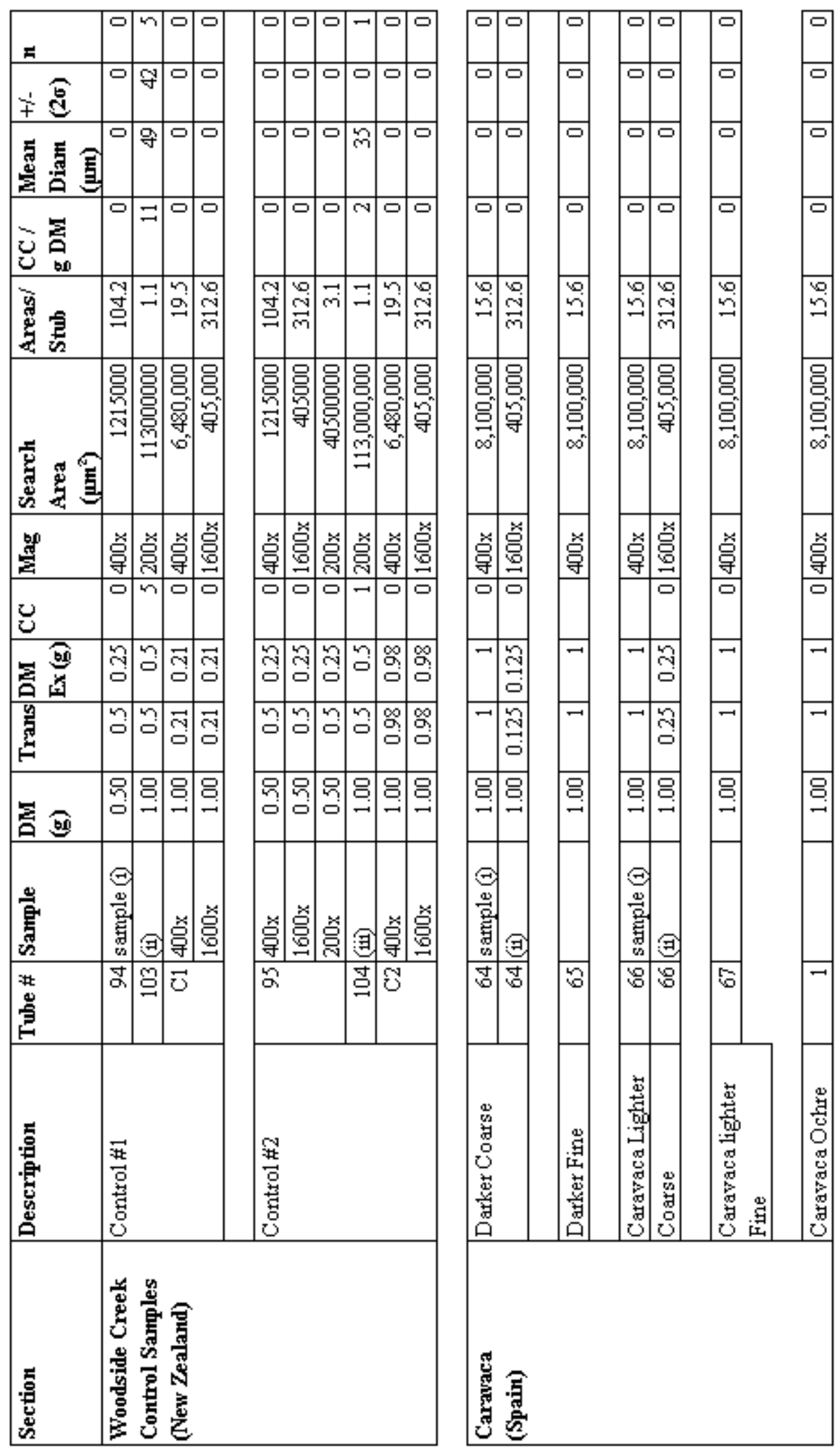

Table DR4: continued 
Harvey et al., page 9

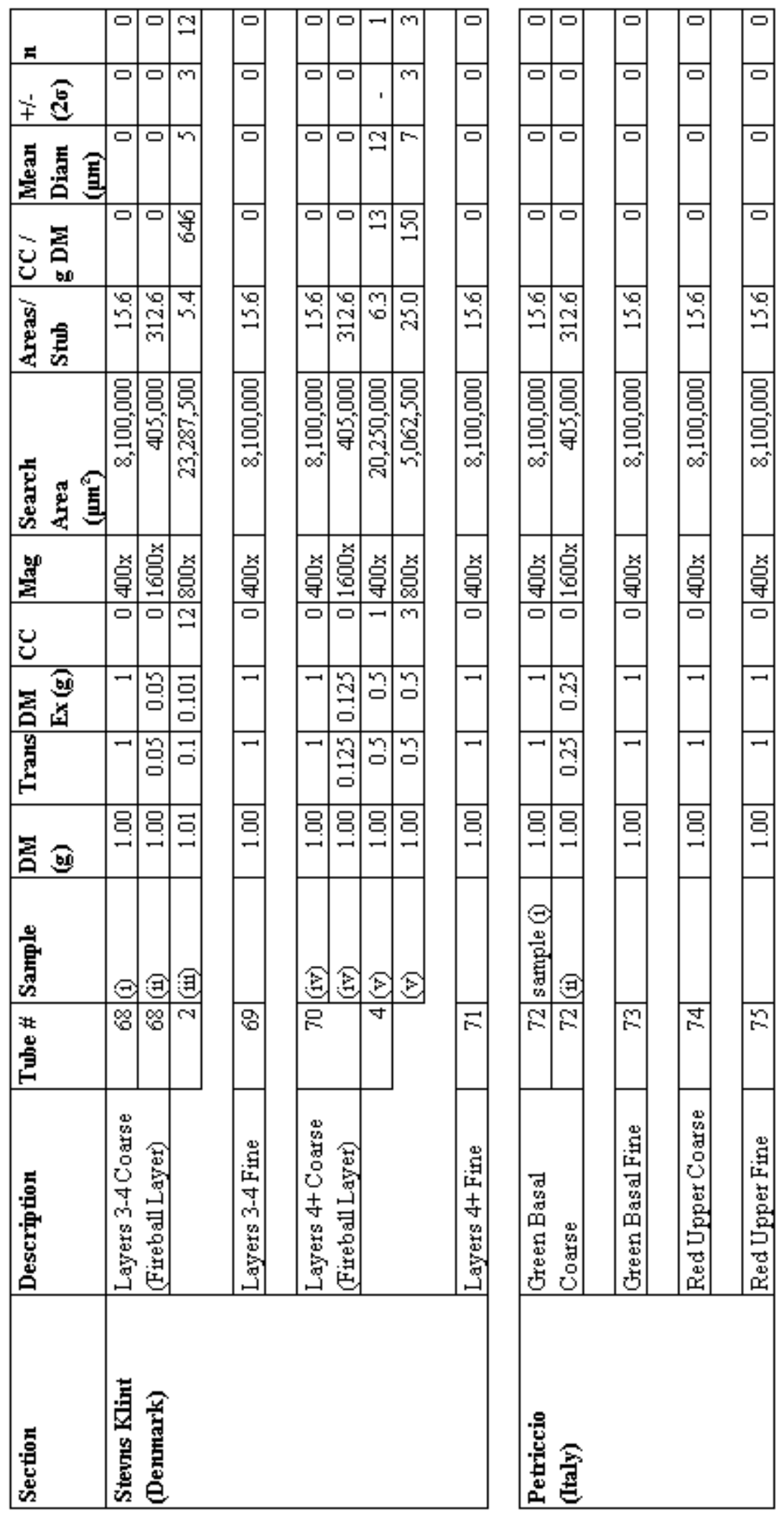

Table DR4: continued 
Harvey et al., page 10

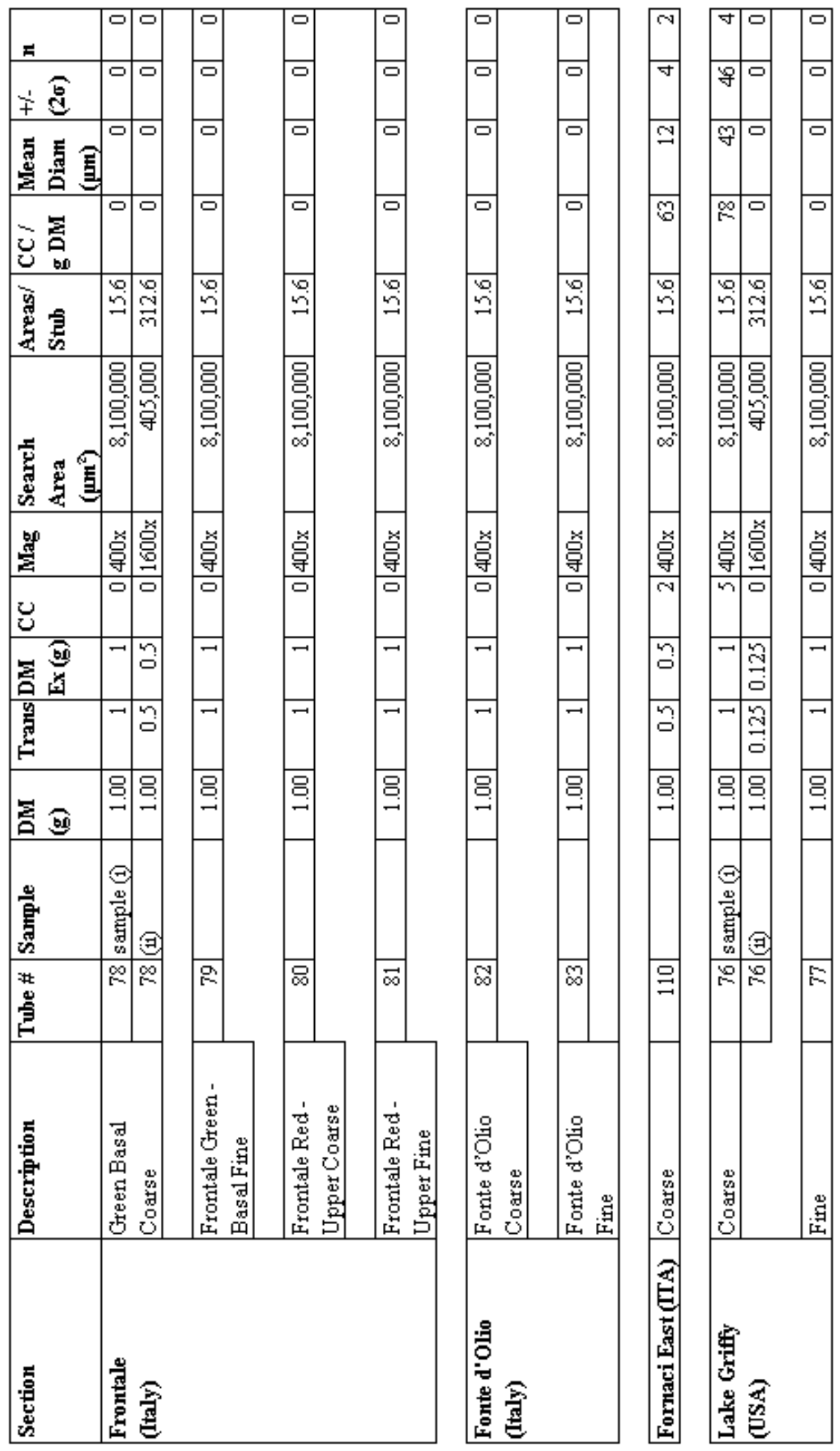

Table DR4: continued 


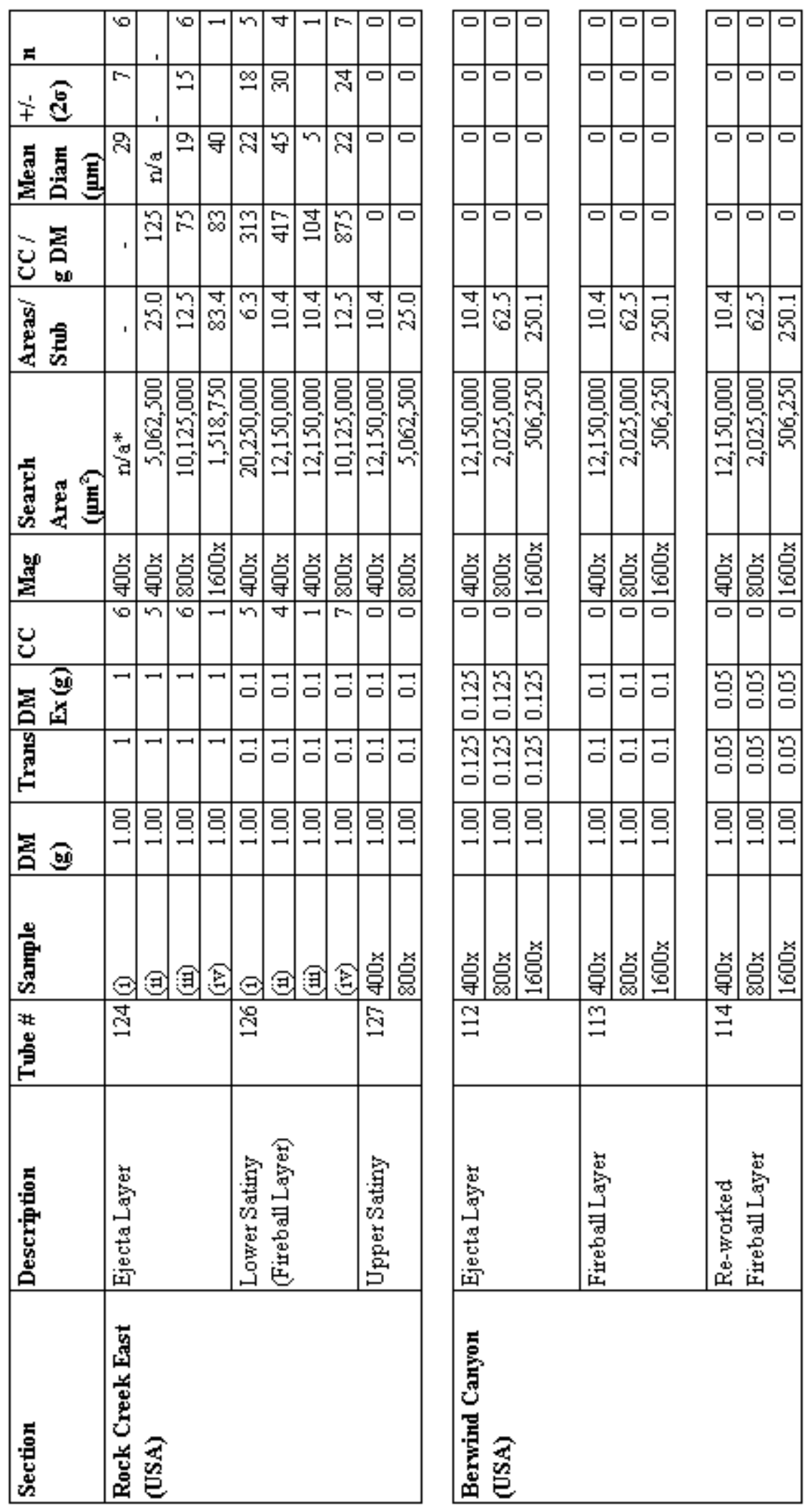

Table DR4: continued 


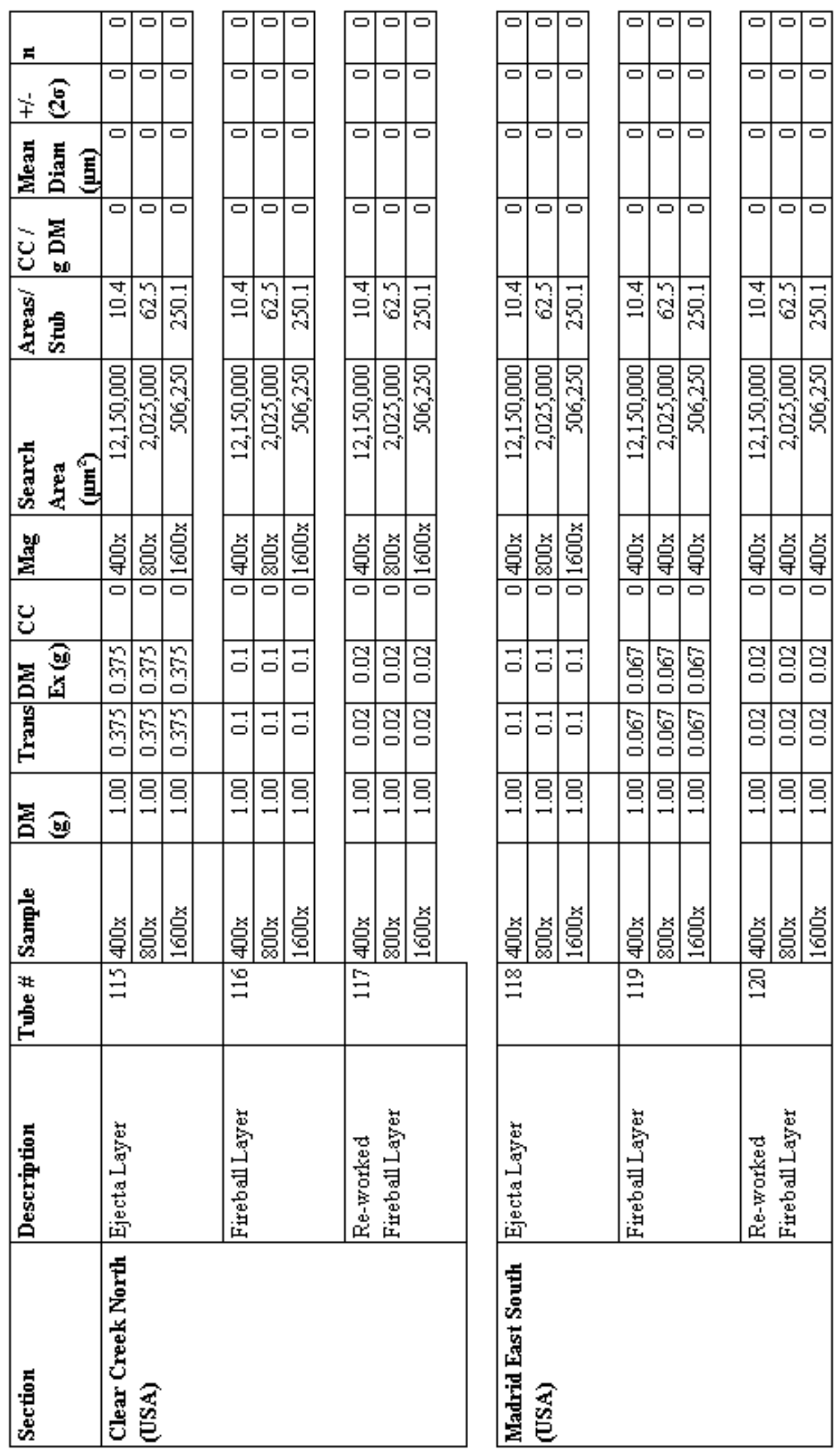

Table DR4: continued 

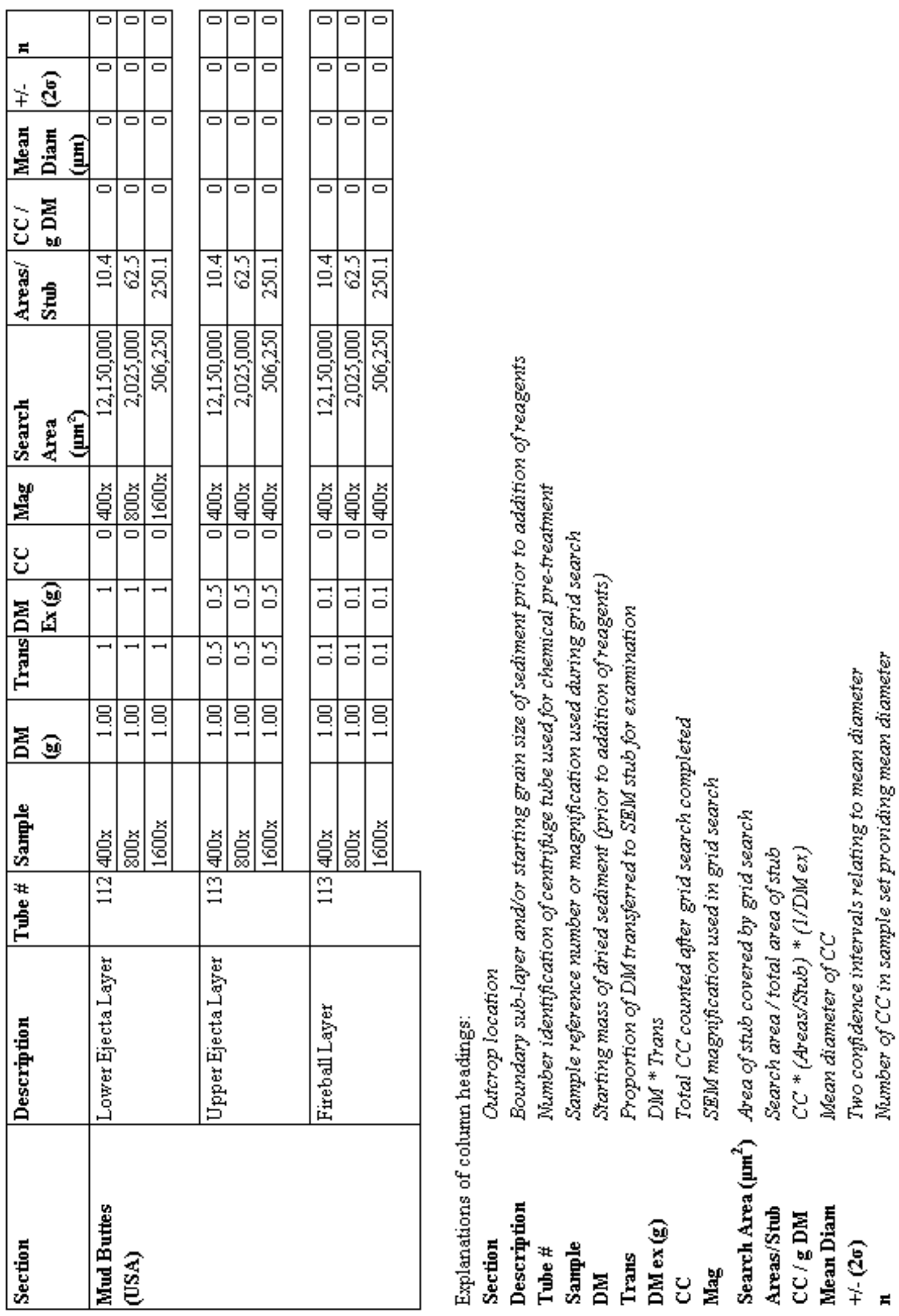

Table DR4: continued 

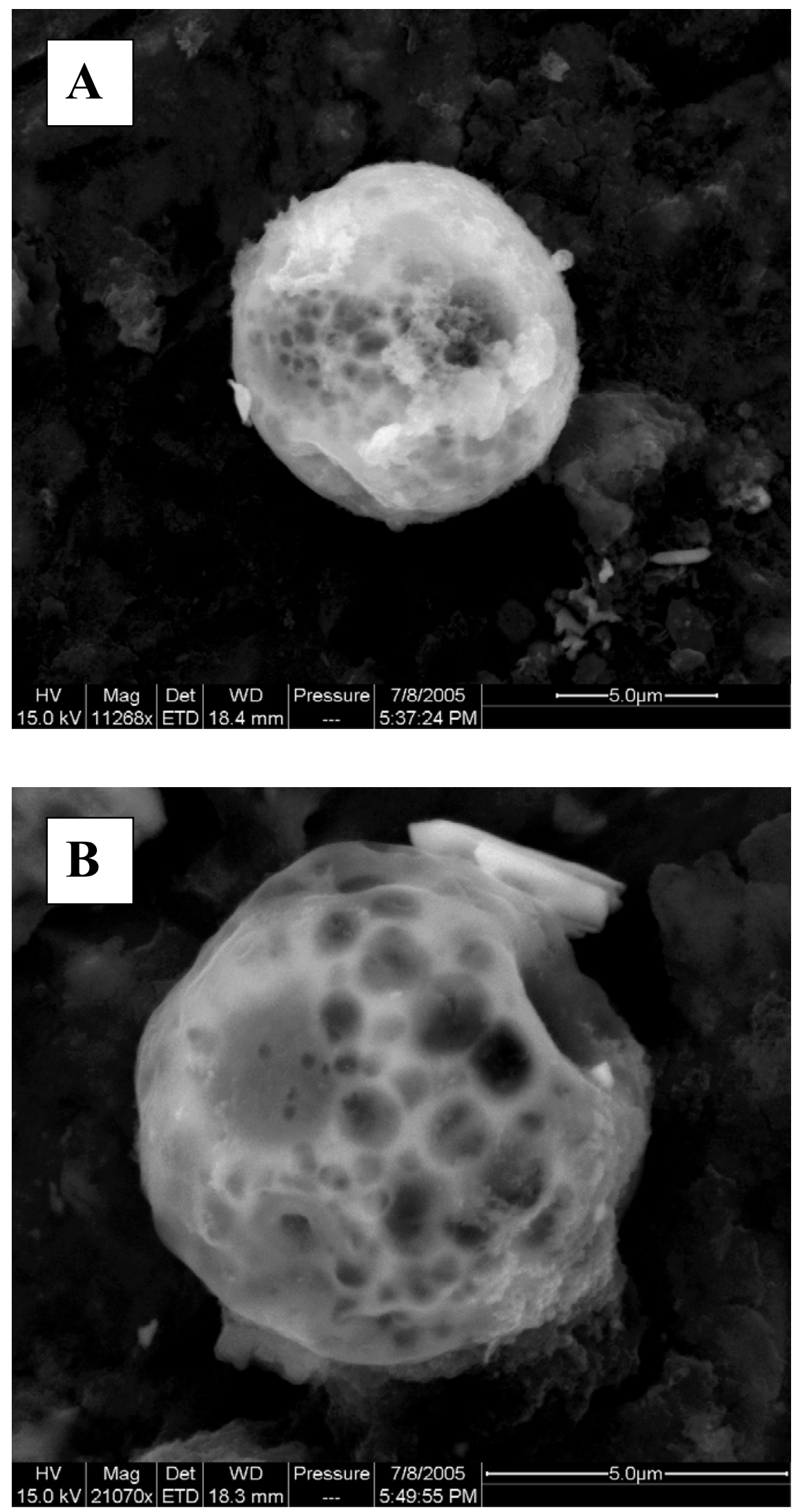

Figure DR1: Woodside Creek K/P boundary CC (see following page for EDS) 

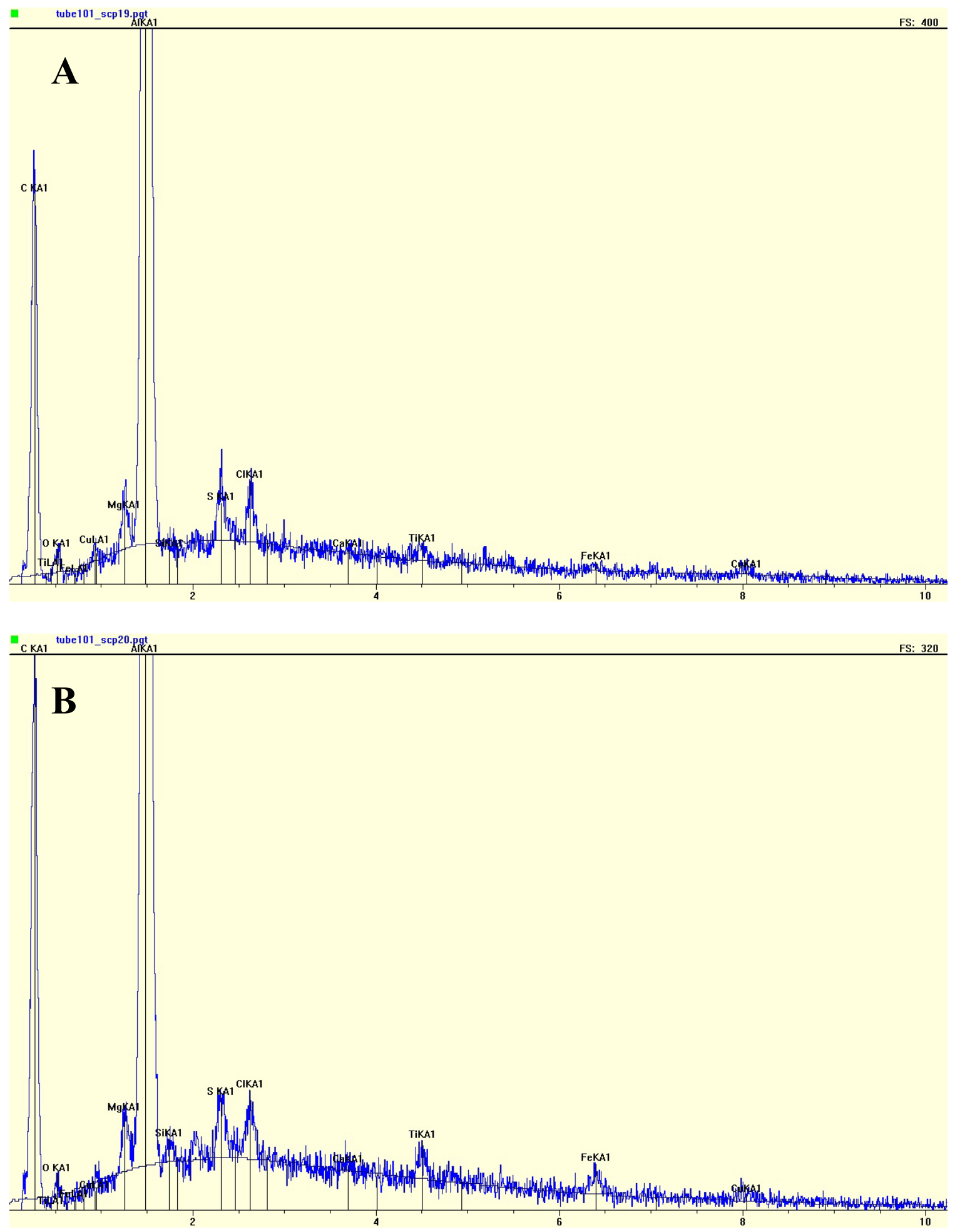

Figure DR2: Energy Dispersive Spectroscopy of Woodside Creek K/P boundary CC (spectra correspond to images (A) and (B) on previous page, respectively). Note: Carbon peak is dominant. Aluminum peak is an artifact of the sample mounting stub. 
Harvey et al., page 16
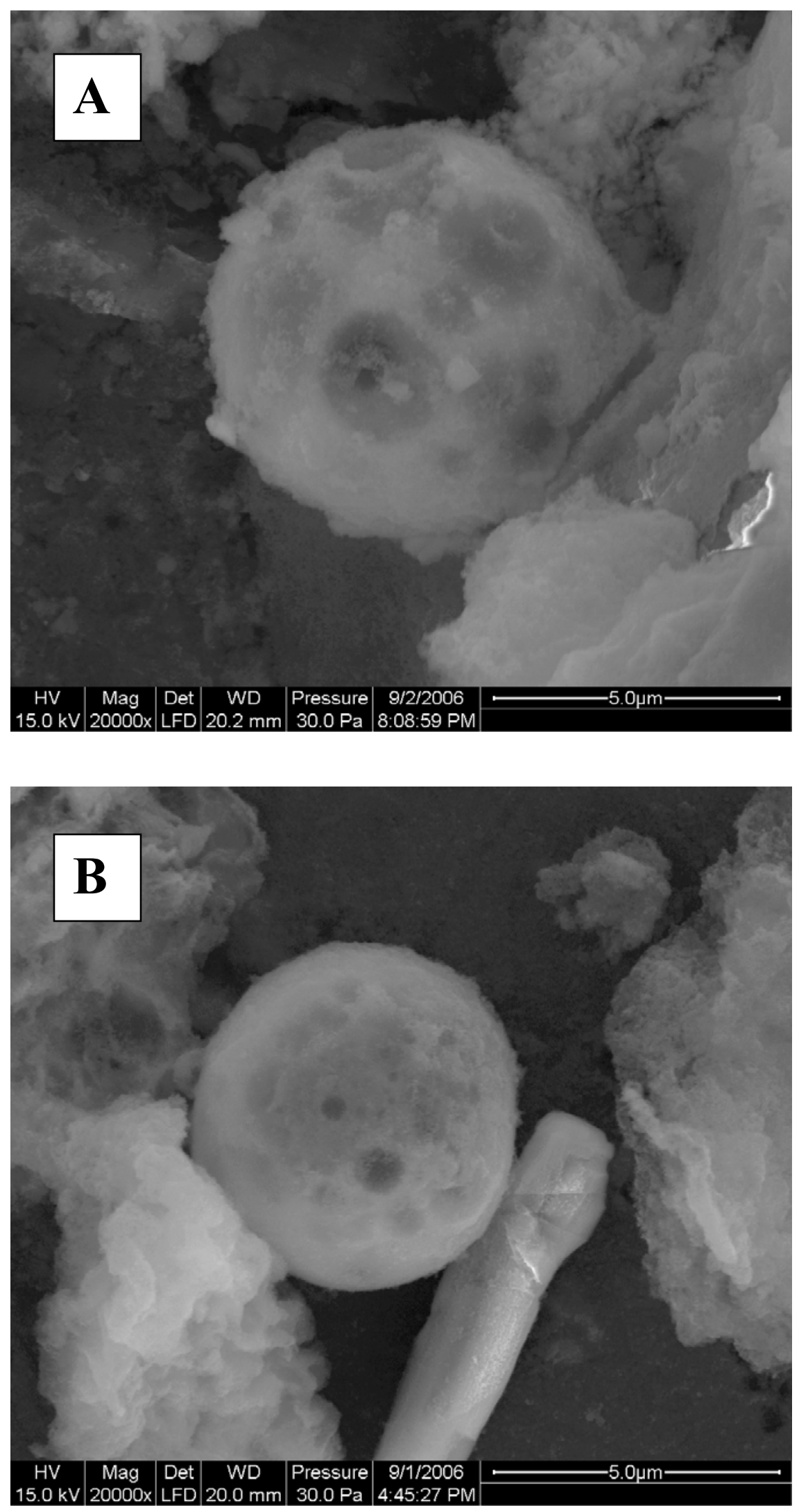

Figure DR3: Stevns Klint K/P boundary CC : Layers 3\&4 (A) and Layer 4+ (B) (see following page for EDS) 

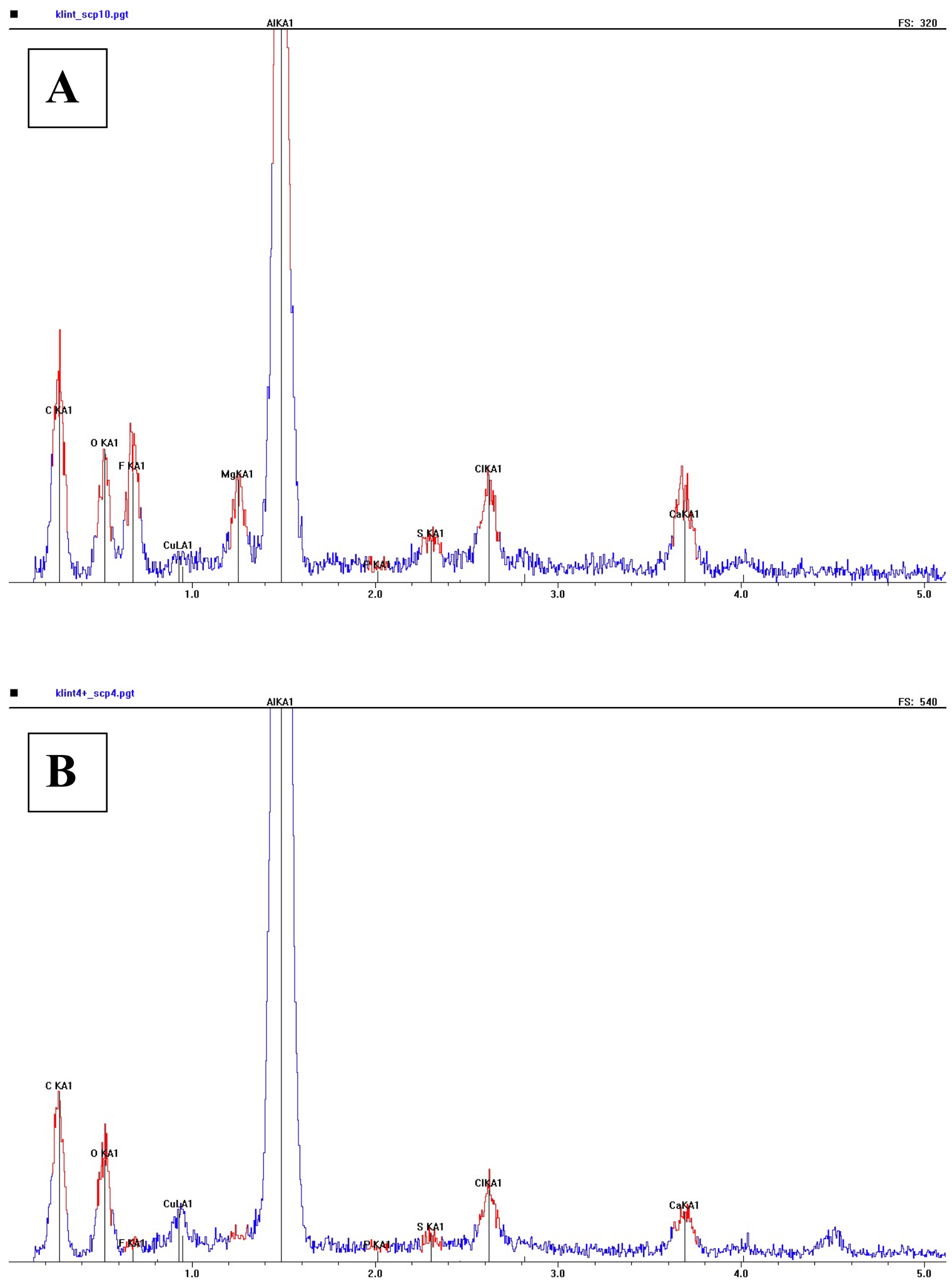

Figure DR4: Energy Dispersive Spectroscopy of Stevns Klint K/P boundary CC (spectra correspond to images (A) and (B) on previous page, respectively). Note: Carbon peak is dominant. Aluminum peak is an artifact of the sample mounting stub. 

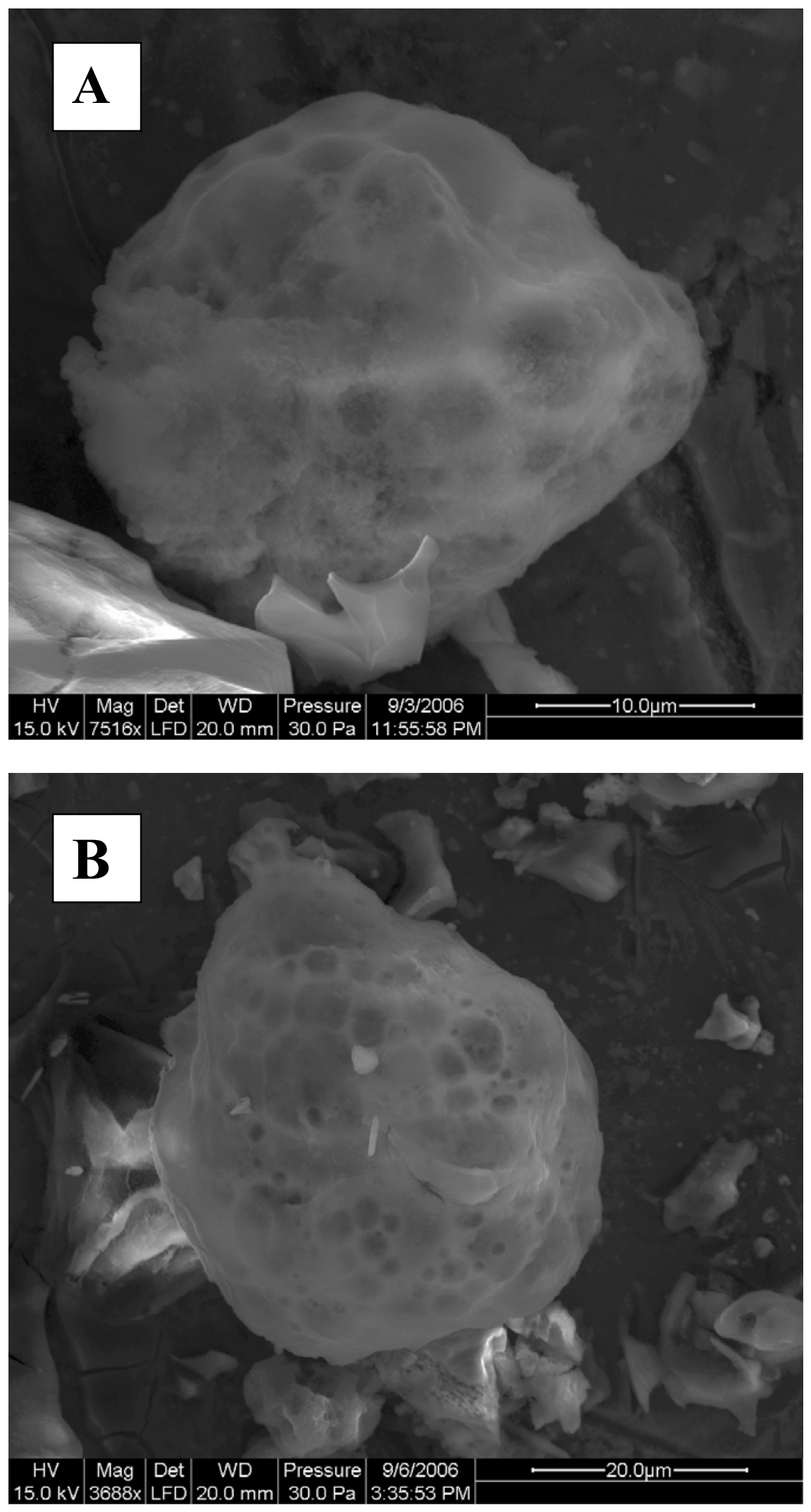

Figure DR5: Rock Creek East K/P boundary CC (see following page for corresponding light microscope images) 

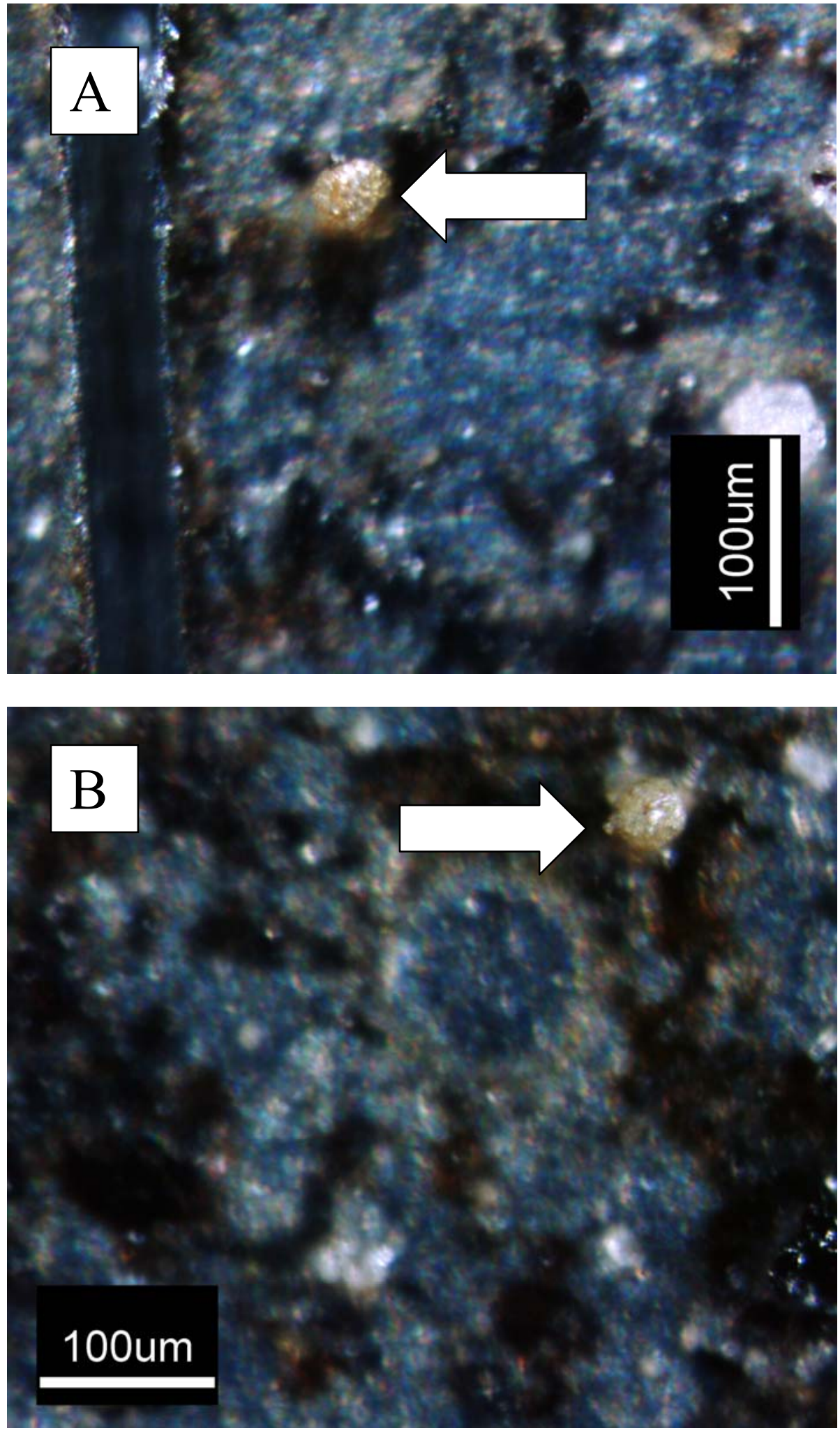

Figure DR6: Light microscope images of Rock Creek East K/P boundary CC (images correspond to (A) and (B) on previous page, respectively). Note: Light brown coloration of CC. 


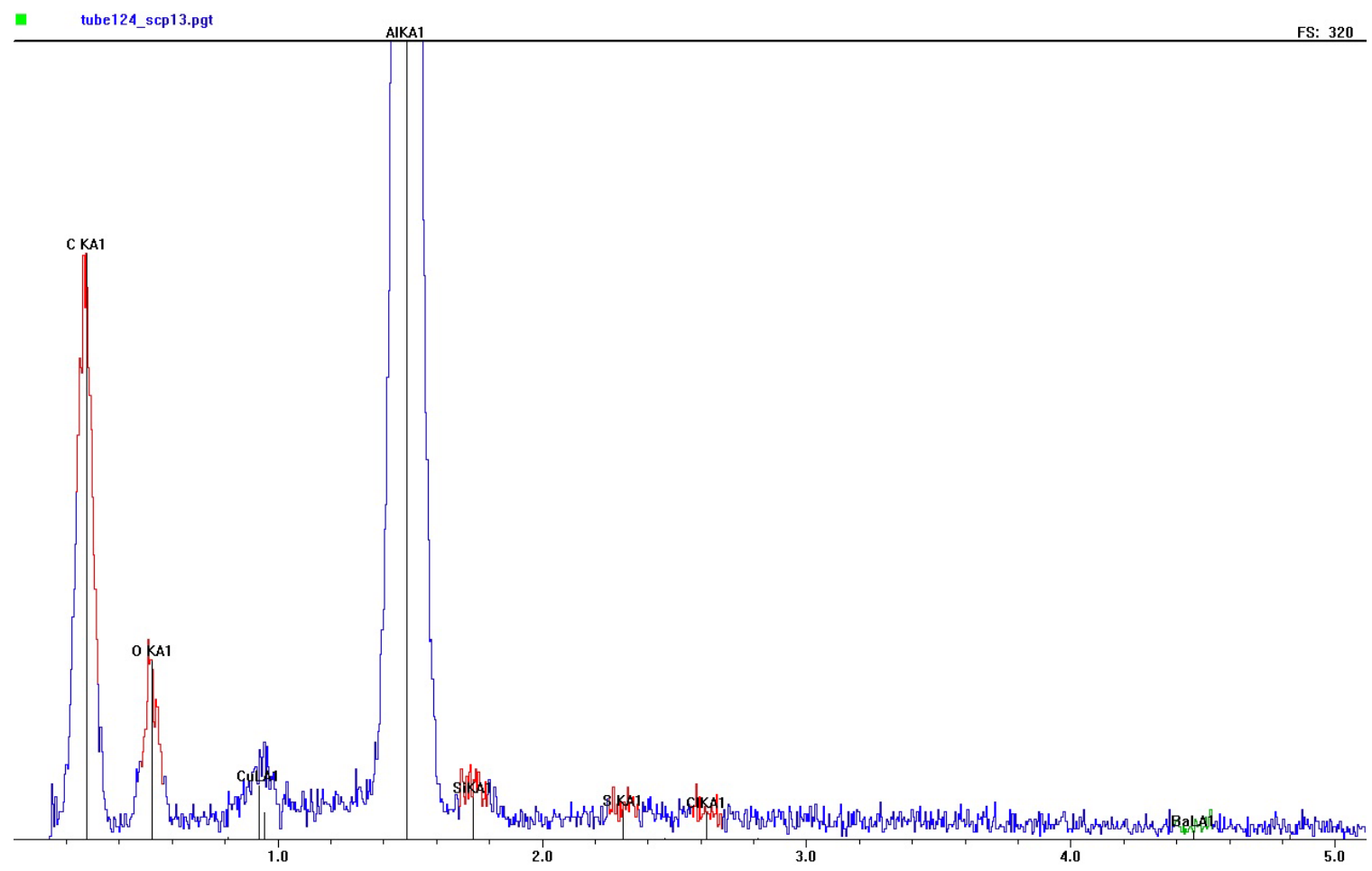

Figure DR7: Energy Dispersive Spectroscopy of Rock Creek East K/P boundary CC (spectra corresponds to image (A) on previous page). Note: Carbon peak is dominant. Aluminum peak is an artifact of the sample mounting stub. 


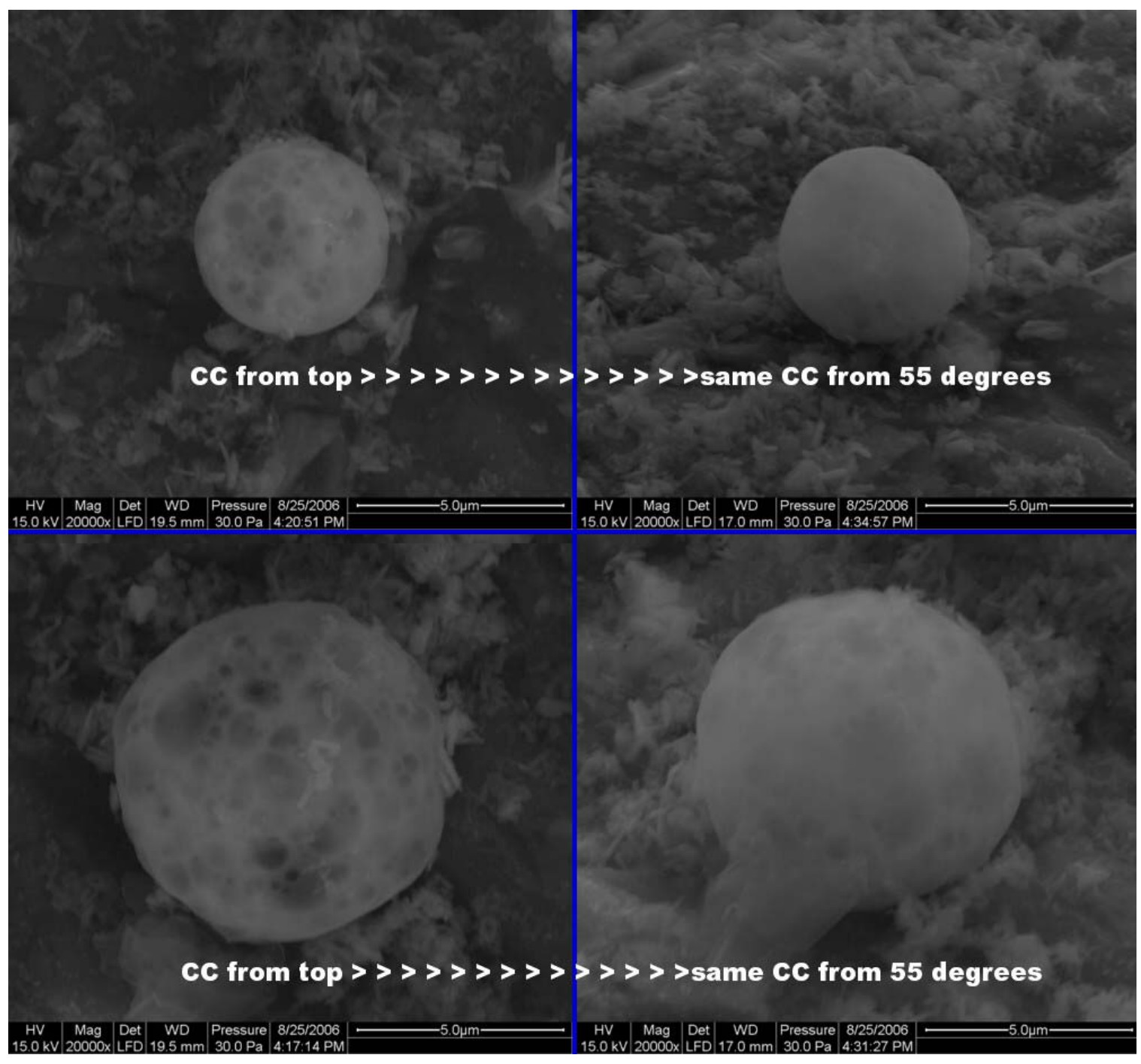

Figure DR8: Woodside Creek K/P Boundary Carbon Cenospheres examined from above (left) and then, from an angle of 55 degrees (right). Note: These images reveal spheroidal morphology. Images at 55 degrees were obtained by tilting the SEM stage. 


\section{Quantification of CC by Grid Search}

\section{Initial Sample Survey}

Sample material was first examined at $1600 \mathrm{x}$ magnification. This level of magnification was found to be capable of efficiently identifying small ( $>2 \mu \mathrm{m}$ diameter) CC. Approximately 20 non-overlapping locations were examined at this magnification. If no $\mathrm{CC}$ were found, the magnification was lowered to $800 \mathrm{x}$ and 20 non-overlapping locations were examined. This level of magnification was found to be capable of efficiently identifying medium size $(>10 \mu \mathrm{m}) \mathrm{CC}$. If no $\mathrm{CC}$ were identified then the magnification was lowered to $400 \mathrm{x}$ and 20 non-overlapping locations checked. This level of magnification was found to be capable of efficiently identifying large size ( $>20$ $\mu \mathrm{m}) \mathrm{CC}$. EDS data were collected for some CC, and all CC diameters were noted.

Note: At 1600x, 800x and 400x magnification, only a small fraction of the SEM stub surface was examined ( $\sim .4 \%, 1.6 \%$ and $6.4 \%$ respectively) in a 20-location search. To allow for possible clumped distribution of CC on the stub surface, the 20 search areas selected for examination were distributed over different parts of the stub. For example, rather than just searching the center of the stub, areas closer to the perimeter were also examined.

\section{Secondary Survey}

If any $\mathrm{CC}$ were discovered in initial survey, further grids were examined in a secondary survey, in order to increase sample size. 


\section{Equation for conversion of $\mathrm{CC}$ tallies to sediment concentration values:}

\begin{tabular}{|c|}
\hline CC / gram Dry Sediment Mass $(\mathrm{CC} / \mathrm{g}$ DM) $=$ \\
\hline $\mathrm{CC}$ tally * total area of SEM stub $\left(\mu \mathrm{m}^{2}\right) /{\text { total area searched }\left(\mu \mathrm{m}^{2}\right)}^{\text {starting dry sediment mass }(\mathrm{g}) * \text { proportion of dry sediment mass examined }}$ \\
\hline
\end{tabular}

Where starting dry sediment mass, the proportion of dry sediment mass examined, the total area searched, and the total area of stub is known. This calculation assumes an even distribution of CC on the SEM stub. Where several tallies are available for one sample (E.g. grid search at 1600x, 800x or 400x provided different tallies - see Quantification of $\mathrm{CC}$ by Grid Search on previous page), the highest magnification tally was used. To allow for possible uneven distribution, the search area was divided into sub-search areas (see Note previous page). 


\begin{tabular}{|c|c|c|c|c|c|c|}
\hline Location & $\begin{array}{l}\text { Depositional } \\
\text { Environment }\end{array}$ & Iridium (ppb) & $\begin{array}{l}\text { Carbon } \\
\text { Abundance } \\
(\mathrm{g} / \mathrm{cm} 2)\end{array}$ & PAH (ppb) & $\begin{array}{l}\text { Shocked } \\
\text { Quartz }\end{array}$ & Spherules \\
\hline $\begin{array}{l}\text { Woodside } \\
\text { Creek (New } \\
\text { Zealand) }\end{array}$ & Marine & $70^{1}$ & $4.8\left({ }^{+} /-0.5\right)^{2}$ & $33^{3}$ & Present $^{5}$ & - \\
\hline $\begin{array}{l}\text { Caravaca } \\
\text { (Spain) }\end{array}$ & Marine & $40^{6}$ & $10(+10 /-1)^{2}$ & 3 (Coronene) & Present ${ }^{5}$ & Present ${ }^{8}$ \\
\hline $\begin{array}{l}\text { Stevns Klint } \\
\text { (Denmark) }\end{array}$ & Marine & $42^{9}$ & $11(+11 /-1)^{2}$ & $30^{3}$ & Present ${ }^{5}$ & Present ${ }^{5}$ \\
\hline $\begin{array}{l}\text { Monte } \\
\text { Pietralata } \\
\text { (Italy) }\end{array}$ & Marine & $2^{10}$ & - & - & - & Present ${ }^{10}$ \\
\hline $\begin{array}{l}\text { Petriccio } \\
\text { (Italy) }\end{array}$ & Marine & $8^{9}$ & - & - & Present ${ }^{11}$ & Present ${ }^{5}$ \\
\hline $\begin{array}{l}\text { Frontale } \\
\text { (Italy) }\end{array}$ & Marine & $5^{10}$ & - & - & - & Present ${ }^{10}$ \\
\hline $\begin{array}{l}\text { Fonte d'Olio } \\
\text { (Italy) }\end{array}$ & Marine & - & - & - & Present ${ }^{10}$ & Present ${ }^{10}$ \\
\hline $\begin{array}{l}\text { Fornaci East } \\
\text { (Italy) }\end{array}$ & Marine & $10^{10}$ & - & - & - & Present ${ }^{10}$ \\
\hline $\begin{array}{l}\text { Berwind } \\
\text { Canyon } \\
\text { (USA) }\end{array}$ & Non-Marine & $\begin{array}{l}\mathrm{Fb}-23 \quad 12,13,14,15 \\
\mathrm{Ej}-\text { low level }\end{array}$ & - & - & Present ${ }^{15}$ & Present ${ }^{15}$ \\
\hline $\begin{array}{l}\text { Clear Creek } \\
\text { North (USA) }\end{array}$ & Non-Marine & $\begin{array}{l}\mathrm{Fb}-14.6^{12,13,14,15} \\
\mathrm{Ej}-0.22\end{array}$ & - & - & Present ${ }^{15}$ & Present ${ }^{15}$ \\
\hline $\begin{array}{l}\text { Madrid East } \\
\text { South (USA) }\end{array}$ & Non-Marine & $\begin{array}{l}\mathrm{Fb}-7.5^{12,13,14,15} \\
\mathrm{Ej}-0.32\end{array}$ & - & - & Present ${ }^{15}$ & Present ${ }^{15}$ \\
\hline $\begin{array}{l}\text { Mud Buttes } \\
\text { (USA) }\end{array}$ & Non-Marine & Not measured & - & - & Present ${ }^{17}$ & Present $^{17}$ \\
\hline $\begin{array}{l}\text { Rock Creek } \\
\text { East } \\
\text { (Canada) }\end{array}$ & Non-Marine & $\begin{array}{l}\mathrm{Fb}-32.6^{16} \\
\mathrm{Ej}--\end{array}$ & - & - & Present ${ }^{16}$ & Present ${ }^{16}$ \\
\hline
\end{tabular}

Table DR5: GENERAL FEATURES OF SAMPLE LOCATIONS

1 Strong et al. (1988)

2 Wolbach et al. (1985)

${ }^{3}$ Venkatesan and Dahl (1989)

${ }^{5}$ Bohor and Modreski (1987)

${ }^{6}$ Smit and ten Kate (1982)

${ }^{7}$ Arinobu et al.(1999)

${ }^{8}$ Smit and Klaver (1981)

${ }^{9}$ Alvarez (1980)

${ }^{10}$ Montenari and Koeberl (2000)

${ }^{11}$ Montenari (1991)

${ }^{12}$ Orth et al. (1981)

${ }^{13}$ Pillmore et al. (1984)

${ }^{14}$ Tshudy et al. (1984)

${ }^{15}$ Izett (1990)

${ }^{16}$ Sweet et al. (1999)

${ }^{17}$ Nichols and Johnson (2002)

$\mathrm{Fb}=$ Fireball Layer

$E j=$ Ejecta Layer $\quad$ Ref from terminology Hildebrand (1993), Belcher et al., (2003) 


\begin{tabular}{lccccccccccc}
\hline \hline Outcrop & A & B & C & D & E & F & G & H & I & J & Global Mass (g) \\
\hline & & & & & & & & & & & \\
Woodside Creek & 4.19 & 28.4 & $1 \mathrm{E}-09$ & 0.001 & 0.28 & 4994 & 4.5 & 0.6 & $5.1 \mathrm{E}+18$ & 33333 & $7.62407 \mathrm{E}+16$ \\
Stevns Klint & 4.19 & 25.7 & $1 \mathrm{E}-09$ & 0.001 & 0.28 & 398 & 4.5 & 10 & $5.1 \mathrm{E}+18$ & 33333 & $9.16298 \mathrm{E}+16$ \\
Rock Creek East & 4.19 & 2197 & $1 \mathrm{E}-09$ & 0.001 & 0.28 & 479 & 4.5 & 1 & $5.1 \mathrm{E}+18$ & 33333 & $9.43742 \mathrm{E}+17$ \\
\hline
\end{tabular}

Table DR6: Mass of Carbon required to produce observed Carbon Cenosphere abundance

\title{
Explanation of column headings:
}

\author{
A: $\quad 4 / 3 \Pi$ \\ B: $\quad$ mean $\mathrm{CC}$ radius cubed $\left(\mu \mathrm{m}^{3}\right)$ from tables DR1,2 \&3 \\ C: $\quad$ conversion $\mu \mathrm{m}^{3}$ to $\mathrm{mm}^{3}$ \\ D: $\quad$ conversion $\mathrm{mm}^{3}$ to $\mathrm{cm}^{3}$ \\ E: $\quad$ CC density $\left(\mathrm{g} / \mathrm{cm}^{3}\right)($ Baltrus et al., 2001) \\ F: $\quad$ mean $\mathrm{CC}$ abundance $(\mathrm{CC} / \mathrm{g})$ from Table DR4 \\ G: $\quad$ K/P boundary sediment density $\left(\mathrm{g} / \mathrm{cm}^{3}\right)$ \\ $\mathrm{H}: \quad \mathrm{K} / \mathrm{P}$ boundary sediment thickness $(\mathrm{cm})$ \\ (Smit and Ten Kate, 1982; Sweet et al., 1999) \\ I: $\quad$ surface area of Earth $\left(\mathrm{cm}^{2}\right)$ \\ J: $\quad \%$ dispersed organic matter converted by combustion to CC (Rose et al., 1996)
}




\section{Stratigraphy Woodside Creek, North-Eastern Marlborough, New Zealand}

The stratigraphy of the Mead Hill K/P boundary section at Woodside Creek, New Zealand, has been described previously by Strong (1977) and Hollis et al. (2003). The following descriptive text outline aspects of the above papers relevant to this research.

\section{The Mead Hill Formation, Marlborough, New Zealand}

The pelagic lithofacies are composed of the late Cretaceous Haumurian, a thickly bedded pale siliceous limestone, the iridium rich boundary clay approximately $(8 \mathrm{~mm}$ thick), and the basal Paleocene Teurian, a thin-bedded dark grey clay-rich calcareous chert. The Haumurian limestones were probably deposited at upper baythal depths of 200-600 m, where as the Teurian strata were probably deposited at 100-200 m depth.

The K/P boundary is well constrained at Woodside Creek, both from the perspective of biostratigraphy and chemostratigraphy. Biologically, the thickly bedded Late Cretaceous limestone is dominated by typical Late Cretaceous foraminifera, and the thinbedded Paleocene chert is dominated by Early Paleocene fauna. Chemically, the boundary clay contains the highest iridium concentration in the southern hemisphere, and one of the highest in the world (70ng/g - Strong et al., 1988). In addition, it contains abundant energy-shocked quartz mineral grains (Bohor et al., 1987), and elevated concentrations of soot (Wolbach et al., 1985), the latter interpreted as evidence for global wildfires at the $\mathrm{K} / \mathrm{P}$ boundary.

The redox conditions of the Woodside Creek K/P boundary depositional environment have been interpreted to be reducing due to the presence of pyrite in the boundary clay (Wolbach et al., 2003). Additionally, the overlying $32 \mathrm{~cm}$ of organic-rich laminated sediment also suggest reducing conditions (Hollis et al., 2003). 


\section{Stratigraphy Scaglia Rossa Formation, Umbria-Marche, Italy}

The stratigraphy of the Scaglia Rossa K/P boundary sections at Petricio, Frontale, Fonte d'Olio, Fornaci East and Furlo - Monte Pietralata, have been described previously by Montanari and Koeberl (2000). As with Woodside Creek, all sites described below for the Umbria/Marche (U/M) region have significant iridium, as well as other trace element anomalies and impact related microspherules (Montanari and Koeberl, 2000). Paleodepths in the U/M region were probably upper baythal $(200-600 \mathrm{~m})$. The following descriptive text outline aspects of stratigraphy specific to each of the $\mathrm{K} / \mathrm{P}$ boundary sites sampled within the $\mathrm{U} / \mathrm{M}$ region.

\section{Petriccio}

The uppermost Cretaceous limestone is bleached white and contains abundant Zoophycos trace fossils. The K/P boundary is well constrained, the $\mathrm{K} / \mathrm{P}$ clay layer being 20-30 $\mathrm{mm}$ thick and containing a thin green basal layer. The K/P layer underlies the overhanging Tertiary limestone containing characteristic basal tertiary Parvularugoglobigerina eugubina fossils. Chemically, the boundary clay at Petriccio contains Iridium at $8.3 \mathrm{ppb}$; abundant microspherules are present along with shocked quartz. The shocked quartz is concentrated in the basal $5 \mathrm{~mm}$ thick green sole of the boundary clay (Montenari, 1991). Redox conditions of the Petriccio K/P boundary depositional environment occurred in two stages with an approximately $5 \mathrm{~mm}$ green basal layer of boundary clay underlying the top $20 \mathrm{~mm}$ of red boundary clay. According to Montanari and Koeberl (2000), the basal green layer was probably deposited during the low oxygen conditions of the mass plankton die-off, the red upper clay layer deposited after the return to normal oxidizing conditions. 


\section{Frontale}

The late Cretaceous limestone grades gradually from pink (30 $\mathrm{cm}$ below boundary) to white (15 cm below boundary). Abundant Zoophycos and Planolites trace fossils with diameters of a few millimeters are filled with reddish brown basal Tertiary sediment. The 15-20 mm thick boundary clay is well constrained, having a thin green basal layer, as at Petriccio, and is well preserved, free of secondary calcite and tectonic shearing. However, the boundary clay does contain frequent and moderately well preserved Cretaceous and lowermost Tertiary planktonic foraminifers, presumably introduced by post K/P boundary bioturbation. The K/P layer underlies the overhanging Tertiary limestone, pink grading upwards into whitish color $3-4 \mathrm{~cm}$ above the base, and containing characteristic basal tertiary Eugubina fossils. The redox conditions of the Frontale K/P boundary depositional environment were very similar to those at Petriccio (described above), with a thin green basal clay layer representing a pulse of low oxygen conditions, underlying the remainder $(\sim 15 \mathrm{~mm})$ of red clay deposited after a return to more oxidizing conditions (Montanari and Koeberl, 2000).

\section{Monte Conero - Fonte d'Olio}

The whitish top Cretaceous limestone has fewer fossils than other locations in the Umbria-Marche basin. The lowermost Tertiary limestone has a light ochre color and is thoroughly homogenized by bioturbation. The boundary clay is entirely ochre-green in color, and quite different from the dual red/green coloration of the K/P layer anywhere else in the Umbria-Marche basin. Chemically, the boundary clay at Fonte d'Olio contains Iridium of $10 \mathrm{ppb}$, the largest in the U-M basin. Altered microkrystites made of

slightly evolved, pale-green glaucony, and shocked quartz are present but there are no goethite microspherules. This pale coloration of the boundary clay indicates an extended period of reducing conditions at the seafloor. Indeed, the lack of goethite spherules in the boundary layer also supports reducing conditions (Montanari and Koeberl, 2000). 


\section{Monte Conero - Fornaci East}

This section has much in common with the nearby Fonte d'Olio outcrop, the topmost Cretaceous and basal tertiary pelagic limestones are light in color suggesting reducing conditions at the paleo-seafloor, but have the normal texture and microfacies of other locations in the Umbria-Marche basin. The $18 \mathrm{~mm}$ thick boundary clay is a pale green color and impact related spherules are present.

\section{Furlo - Monte Pietralata}

The light pink top Cretaceous limestone is bioturbated, and the lowermost 2-m-thick interval of Tertiary limestone consists of thin bedded, dark pink platy limestones. The boundary layer here is $8 \mathrm{~mm}$ thick and lacks the green sole typical of the $\mathrm{K} / \mathrm{P}$ boundary in the U-M region. Chemically, the boundary clay at Furlo contains only a low concentration of Ir (1-2 ppb) compared to other sites in this region. The strong bioturbation and vertical mixing present at this site may indicate relatively oxygenic conditions 


\section{Stratigraphy of the Maastrichtian/Danian section, Stevns Klint, Denmark}

The stratigraphy of the Maastrichtian/Danian section at Stevns Klint was described previously by Christensen et al. (1973). The Maastrichtian is represented by the lower $35 \mathrm{~m}$ of white chalk with large content of bryozoans, Zoophycos and flint nodules. The latest Maastrichtian is represented by a thick layer of grey chalk, and is abruptly overlain by a dark grey marl band, the so-called fish clay and the basal Danian bed. The K/P boundary, or fish clay is well described, having been sub-divided by Christensen et al. (1973) into 4 layers (from bottom to top): (i) A grey laminated marl, (ii) black marl with pyrite concretions, (iii) black laminated marl with pyrite considered to be the 'fireball' or 'impact' layer, (iv) light grey marl with flattened lenses of white chalk which grades into indurated Cerithium limestone. The depositional environment was shallow water marine, approximately 40 meters in depth. Chemically, the boundary clay at Stevns Klint contains Iridium of 42 ppb (Alvarez et al., 1980), impact glasses and shocked quartz (Bauluz et al., 2000). The fine laminations in layer (iv) and pyrite concretions in layer (iii) noted by Christensen et al. (1973) suggest euxinic redox conditions for the depositional environment. 


\section{Stratigraphy of Caravaca, Spain}

The stratigraphy of the Barranco del Gredero section is described in detail by Smit and Klaver (1981), Smit and ten Kate (1982) and Smit (2005). The following descriptive text outline aspects of the Caravaca $\mathrm{K} / \mathrm{P}$ boundary section relevant to this research.

The Barranco del Gredero section is Milankovitch in style, well bedded from early Maastrichtian through to Lower Eocene and over 225m thick. By comparison, the well known section at Gubbio in Italy represents the same interval, but is only $10.5 \mathrm{~m}$ thick (Smit, 2005). The lithologies of the uppermost Cretaceous and lowermost Tertiary are similar with alternations of hemi-pelagic marls and marly limestones inter-dispersed with minor amounts of hard pelagic limestones and calciturbidites (Smit and ten Kate, 1982). A 10-12 cm thick dark clayey marl bed forms the boundary at Barranco del Gredero, with a basal red layer $(0.5 \mathrm{~cm})$ and a green-gray upper layer $(8-12 \mathrm{~cm})$ gradually growing lighter towards the top and underlying the classic basal Barranco del Gredero Tertiary P.eugabina zone (Smit and ten Kate, 1982). In addition the boundary layer contains abundant tiny sanidine spherules, interpreted as the remains of impactor melt droplets (Smit and Klaver, 1981). The depth of deposition at Barranco del Gredero was approximately $1000 \mathrm{~m}$ as suggested by the presence of mesopelagic fish teeth (Smit, 2005). Geochemically, the boundary clay at Barranco del Gredero contains anomalously high concentrations of $\mathrm{Cr}, \mathrm{Ni}, \mathrm{As}, \mathrm{Sb}, \mathrm{Zn}$ and platinum group elements including iridium (40 ppb) (Smit and ten Kate, 1982). In addition the boundary layer contains abundant shocked quartz (Bohor and Modreski, 1987). 


\section{Stratigraphy of North American Sites}

In contrast to other sites in this study, all North American sections are non-marine. North American sections contain two distinctive claystone layers. The lower welllithified creamy colored claystone layer (the "ejecta layer" of Hildebrand [1993]); "hackly layer" of Sweet et al. [1999]) is 7-27 mm thick and composed of kaolinite with some melt spherules. The kaolinite darkens upward and texture becomes finer toward a sharp contact with the overlying layer. The upper layer ("impact layer" of Izett [1990]; "fireball layer" of Hildebrand [1993], "satiny layer" of Sweet et al. [1999]) is less lithified than the lower layer, is $2-10 \mathrm{~mm}$ thick, and is composed of beige to brown claystone. The upper layer contains numerous cream oval-shaped pellets or graupen with long axis aligned parallel to bedding, and thin vitrinite laminae. An iridium anomaly and shocked minerals occur in this layer (Hildebrand, 1993). 


\section{References}

Alvarez, L.W., Alvarez, W., Asaro, F. and Michel, H., 1980, Extraterrestrial cause for the Cretaceous-Tertiary extinction: Science, v. 208, p. 1095-1108.

Arinobu, T., Ishiwatari, R., Kaiho, K. and LaMolda, M.A., 1999, Spike of pyrosynthetic polycyclic aromatic hydrocarbons associated with an abrupt decrease in delta C-13 of a terrestrial biomarker at the Cretaceous-Tertiary boundary at Caravaca, Spain: Geology, v. 27, p. 723-726.

Baltrus, J.P., Wells, A.W., Fauth, D.J., Diehl, J.R. and White, C.M., 2001, Characterization of carbon concentrates from coal-combustion fly ash: Energy and Fuels, v. 15, p. 455-462.

Bauluz, B., Peacor, D., and Elliot, C., 2000, Coexisting altered glass, Fe-Ni oxides, and shocked spherules at the K-T boundary, Stevns Klint (Denmark): Direct evidence of meteorite impact: The Journal of Conference Abstracts, v. 5, p. 201.

Belcher, C.M., Collinson, M.E., Sweet, A.R., Hildebrand, A.R. And Scott, A.C., 2003, "Fireball Passes and Nothing Burns" the role of thermal radiation in the K-T event: evidence from the charcoal record of North America: Geology, v. 31, p. 1061-1064.

Bohor, B.F., and Modreski, P.J., 1987, Shocked quartz in the Cretaceous-Tertiary boundary clays: Evidence for a global distribution: Science, v. 236, p. 705-709.

Christensen, L., Fregerslev, S., Simonsen, A. and Thiede, J., 1973, Sedimentology and Depositional environment of Lower Danien fish clay from Stevns Klint, Denmark: Bulletin of the Geological Society of Denmark, v. 22, p.193-212.

Hildebrand, A.R., 1993, The Cretaceous/Tertiary Impact (or the dinosaurs didn't have a chance): Journal of the Royal Astronomical Society of Canada, v. 87, p. 77-118.

Hollis, C.J., Strong, C.P., Rodgers, K.A., and Rogers, K.M., 2003, Paleoenvironmental changes across the Cretaceous-Tertiary boundary at Flaxbourne River and Woodside Creek, eastern Marlborough, New Zealand: New Zealand Journal of Geology and Geophysics, v. 46, p. 177-197.

Izett, G.A., 1990, The Cretaceous/Tertiary Boundary Interval, Raton Basin, Colorado and New Mexico, and its Content of Shock-Metamorphosed Minerals, Evidence Relevant to the K/T Boundary Impact-Extinction Theory: Geological Society of America, Special Papers, v. 249

Montenari, A., 1991, Authigenisis of impact spheroids in the K/T boundary clay from Italy: new constraints for high-resolution stratigraphy of the terminal Cretaceous events: Journal of Sedimentary Geology, v. 61, p. 315-339.

Montanari, A., and Koeberl, C., 2000, Impact Stratigraphy the Italian Record. SpringerVerlag: New York, p. 222-244. 
Nichols, D.J., and Johnson, K.R., 2002, Palynology and microstratigraphy of CretaceousTertiary boundary sections in southwestern North Dakota. In Hartman, JH., Johnson, KR. And Nichols DJ (eds) The Hell Creek Formation of the Cretaceous-Tertiary Boundary in the North Western Great Plains: Geological Society of America, Special Papers, v. 361, p. 95-143.

Orth, C.J., Gillmoe, J.S., Knight, JD., Pillmore, CI., Tshudym RH. And Fassett, JE., 1981, An iridium abundance anomaly at the palynological Cretaceous-Tertiary boundary in north New Mexico: Science, v. 214, p. 1341-1342.

Pillmore, C.I., Tshudy, R.H., Orth, C.J., Gilmore, J.S., and Knight, J.D., 1984, Geologic framework of nonmarine Cretaceous-Tertiary boundary sites, Raton Basin, New Mexico and Colorado: Science, v. 223, p. 1180-1183.

Rose, N.L, Juggins, S., and Watt, J., 1996, Fuel-type characterization of carbonaceous fly-ash particles using EDS-derived surface chemistries and its application to particles extracted from lake sediments: Proceedings of the Royal Society of London: v. 452, p. 881-907.

Smit, J., and Klaver, G., 1981, Sanidine spherules at the Cretaceous-Tertiary boundary indicate a large impact event: Nature, v. 292, p. 47-49.

Smit, J. and ten Kate, W.G.H.Z., 1982, Trace element patterns at the Cretaceous-Tertiary Boundary - Consequences of a large impact: Cretaceous Research, v. 3, p. 307-332.

Smit, J., 2005, The section of the Barranco del Gredero (Caravaca, SE Spain): a crucial section for the Cretaceous/Tertiary boundary impact extinction hypothesis: Journal of Iberian Geology, v. 31, p. 179-191.

Strong, C.P. 1977, Cretaceous-Tertiary boundary at Woodside Creek, north-eastern Marlborough: New Zealand Journal of Geology and Geophysics, v. 20, p. 687-696.

Strong, C.P., Brooks, R.R., Orth, C.J. and Mao, X.Y., 1988, An iridium-rich calcareous claystone (Cretaceous-Tertiary boundary) from Wharanui, Marlborough, New Zealand: New Zealand Journal of Geophysics, v. 31, p. 191-195.

Sweet, A.R., Braman, D.R. and Lerbekmo, J.F., 1999, Sequential palynological changes across the composite K-T boundary claystone and contiguous strata, western Canada and Montana, USA: Canadian Journal of Earth Science, v. 36, p. 743-768.

Tshudy, R.H., Pillmore, C.I., Orth, C.J., Gillmore, J.S., and Knight, J.D., 1984, Disruption of the terrestrial plant ecosystem at the Cretaceous-Tertiary boundary, Western Interior: Science, v. 225, p. 1030-1032.

Venkatesan, M.I., and Dahl, J., 1989, Organic geochemical evidence for global fires at the Cretaceous/Tertiary boundary: Nature, v. 338, p. 57-60. 
Wolbach, W.S., Lewis, R.S. and Anders, E., 1985, Cretaceous extinctions; Evidence for wildfires and search for meteoritic material: Science, v. 230, p. 167-170.

Wolbach, W.S., Widicus, S., and Kyte, F.T., 2003, A search for soot from global wildfires in central pacific Cretaceous-Tertiary boundary and other extinction and impact horizon sediments: Astrobiology, v. 3, p. 91-97. 